\title{
Grape berry bacterial inhibition by different copper fungicides
}

\author{
Guilherme Martins ${ }^{1,2}$, Cécile Miot-Sertier ${ }^{1}$, Aline Lonvaud-Funel ${ }^{1}$, and Isabelle Masneuf-Pomarède ${ }^{1,2}$ \\ ${ }^{1}$ USC CEnologie- INRA, Université Bordeaux Segalen, ISVV, Villenave d'Ornon, France \\ ${ }^{2}$ Bordeaux Sciences Agro, Gradignan Cedex, France
}

\begin{abstract}
Copper fungicides are widely used in viticulture. Due to its large spectrum of action, copper provides an efficient control over a great number of vine pathogens. Previous studies showed that, high levels of cupric residues can impact grape-berry microbiota, in terms of the size and population structure, reducing the diversity and the abundance. Due to the importance of grape-berry bacterial in crop health, and the potential impact of copper fungicides over the microbiota, we determined Minimum Inhibitory Concentration (MIC) of different copper formulations for bacterial species isolated from grape berries. We study the Minimum Inhibitory Concentration (MIC) of different copper formulations (copper sulphate (CuSO4) pure, Bordeaux mixture $(\mathrm{CuSO} 4+\mathrm{Ca}(\mathrm{OH}) 2)$, copper oxide $(\mathrm{Cu} 2 \mathrm{O})$, copper hydroxide $(\mathrm{Cu}(\mathrm{OH}) 2))$ over 92 bacterial strains isolated from grape berries in different stages of the ripening process. The results of MIC measurements revealed that the different copper formulations have a variable inhibitory effect and among the different isolates, some species are the most resistant to all copper formulations than others. This study confirm that usage of cupric phytosanitary products should be reasonable independently of the farming system; they also provide evidence of the importance of the choice of which copper formulations are to be used regarding their impact on the grape berry bacterial microbiota.
\end{abstract}

\section{Introduction}

Copper-based fungicides have been used for more than 2 centuries to control fungi and bacteria vine pathogens. According with the Copper Development Association, copper utilisation in viticulture can be traced back to 1880 , when the vinters from Bordeaux area who used a mixture of copper sulphate and lime to prevent passers-by from peaking grapes realize that these grapes did not show any signs of downy mildew.

In addition to its action against downy mildew, copperbased fungicides are very effective in curative treatment of bacterial necrosis. Furthermore, copper does not present problems in terms of pathogen resistance. The use of copper-based fungicides is a shared practice in both organic and conventional farming systems.

Copper-based molecules are particularly important in organic viticulture once they replace synthetic chemical pesticides. However, previous research showed that high levels of cupric residues can impact grape-berry microbiota, in terms of the size and population structure, reducing the diversity and the abundance (Martins et al. 2012 and 2013).

The surface of grape berries represents a natural reservoir of bacterial microbiota that has various impacts on the also in crop quality and yields and may influence the winemaking process, with major repercussions on wine quality (Barbe et al. 2001, Bae et al. 2006, Nisiotou et al. 2006).

Due to the importance of bacterial associated grapeberry in crop health, and the potential impact of copper fungicides over this microbiota, we determined
Minimum Inhibitory Concentration (MIC) of different copper formulations for bacterial species isolated from grape berries.

\section{Materials and methods}

Isolates collection and re-plating

The different copper formulations were tested in a collection of 92 bacterial strains isolated from grape berries in 2009, in the Libourne wine area (southwest of France), in different stages of the ripening process. The grape sampling, microbial recovery and colony isolation were made according with Martins et al. 2012. All the strains used in this study are part of the CRB OEnologie collection (www.crboeno.univ-bordeauxsegalen.fr) (Université de Bordeaux, France).

Strains were cultured in $1 / 10$ diluted LB culture media: ( $1 \mathrm{~g} \mathrm{~L}-1$ bactotryptone, $1 \mathrm{~g} \mathrm{~L}-1$ yeast extract, $0.5 \mathrm{~g} \mathrm{~L}-1$ $\mathrm{NaCl}$, and $20 \mathrm{~g} \mathrm{~L}-1$ agar) and $150 \mathrm{mg} \mathrm{L}-1$ biphenyl (Acros) to inhibit yeast and mould growth. The fresh colonies were picked and suspended in physiological serum $(0,9 \% \mathrm{NaCl})$. Cell concentration was measured and adjusted to $10^{2} \mathrm{cfu} \mathrm{m} / \mathrm{L}$.

\section{Different copper formulations}

The culture medium was poured in square Petri dishes in which are added the different copper formulations (i.e. copper sulphate (CuSO4) pure, Bordeaux mixture $(\mathrm{CuSO} 4+\mathrm{Ca}(\mathrm{OH}) 2)$, copper oxide $(\mathrm{Cu} 2 \mathrm{O})$ the active ingredient contained in Nordox 74 WG (Nordox, 
Table 1. Effect of different cooper formulation over the collection of 92 bacterial.

\begin{tabular}{cc}
\hline $\begin{array}{c}\text { Bordeaux mixture }(\mathbf{C u S O 4}+\mathbf{C a}(\mathbf{O H}) \mathbf{2}) \\
\begin{array}{c}\text { Concentration } \\
\mathrm{mg} / \mathrm{mL}\end{array}\end{array}$ & $\begin{array}{c}\text { percentage of the species who } \\
\text { didn't show visible growth }\end{array}$ \\
\hline 16 & 1,1 \\
8 & 51,1 \\
4 & 45,7 \\
2 & 2,2 \\
\hline \multicolumn{2}{c}{ copper oxide $(\mathbf{C u 2 O})$} \\
Concentration & percentage of the species who \\
$\mathrm{mg} / \mathrm{mL}$ & didn't show visible growth \\
\hline 32 & 67,39130435 \\
32 & 19,56521739 \\
16 & 7,608695652 \\
8 & 1,086956522 \\
4 & 2,173913043 \\
2 & 2,173913043 \\
\end{tabular}

AS - Oslo, Norway), copper hydroxide $(\mathrm{Cu}(\mathrm{OH}) 2)$ the active ingredient contained in Champ ${ }^{\mathrm{TM}}$ Flo (Nufarm, Auckland, New Zealand), diluted successively from stock solution ranging from $32 \mathrm{mg} / \mathrm{ml}$ to $0,0035 \mathrm{mg} / \mathrm{ml}$.

\section{Determination MIC (photo of Steers apparatus)}

Microorganisms were seeded using a Steers multipoint inoculators, this device allowed the inoculation of 48 wells onto which $10 \mu \mathrm{L}$ of each standardized microbial inoculum were transferred to the Petri dish equidistantly from each other. The dishes were then incubated during 72 hours at $30^{\circ} \mathrm{C}$.

Petri dishes without any cupric products were seeded as control test in order to detect any contamination and ensure cell viability during the inoculation process.

Readings were performed by comparing the growth on the Petri dishes contained cupric products with control test dishes. The minimum inhibitory concentration (MIC) was determined as the lowest concentration of copper formulation that inhibits the visible growth of a microorganism after the incubation period.

\section{Results}

\section{Determination of the Minimum Inhibitory Concentration (MIC)}

The copper sulphate with or without any excipient, presented the highest inhibitory activity: the MIC of the copper sulphate without any excipient was $1 \mathrm{mg} / \mathrm{mL}$ for $20,7 \%, 2 \mathrm{mg} / \mathrm{mL}$ for $70,7 \%$ and $4 \mathrm{mg} / \mathrm{mL}$ for $7,6 \%$ of the percentage the bacteria tested (Table 1). Only one isolate showed a MIC of $8 \mathrm{mg} / \mathrm{mL}$ (Micrococcus endophyticus). Regarding the Bordeaux mixture, the MIC varied between 4 and $8 \mathrm{mg} / \mathrm{L}$ for $96 \%$ of the isolates. Only one isolate showed a MIC higher than $16 \mathrm{mg} / \mathrm{mL}$ (Pseudomonas graminis).

As to copper hydroxide; it prevents visible growth of $48 \%$ of the individuals with concentrations equal to or less than $16 \mathrm{mg} / \mathrm{mL}$. Copper oxide was the formulation which showed the highest values of MIC, $80 \%$ of the isolates grow with concentrations higher than $32 \mathrm{mg} / \mathrm{mL}$.

\begin{tabular}{cc}
\hline \multicolumn{2}{c}{ Copper sulphate CuSO4 } \\
$\begin{array}{c}\text { Concentration } \\
\mathrm{mg} / \mathrm{mL}\end{array}$ & $\begin{array}{c}\text { percentage of the species who } \\
\text { didn't show visible growth }\end{array}$ \\
\hline 8 & 1,1 \\
4 & 7,6 \\
2 & 70,7 \\
1 & 20,7 \\
\hline \multicolumn{2}{c}{ Copper hydroxide $(\mathbf{C u}(\mathbf{O H}) \mathbf{2})$} \\
Concentration & percentage of the species who \\
$\mathrm{mg} / \mathrm{mL}$ & didn't show visible growth \\
\hline$>32$ & 25 \\
32 & 27,17391304 \\
16 & 17,39130435 \\
8 & 17,39130435 \\
4 & 7,608695652 \\
2 & 3,260869565 \\
0,007 & 2,173913043 \\
\hline
\end{tabular}

Among all isolates, the species Pantoea agglomerans, Enterobacter cowani, Micrococcus endophyticus and Pseudomonas graminis are the most resistant to copper fungicides tested. In contrast Pseudomonas congelans, Frigoribacterium faeni and Pseudomonas cannabina showed to be the most sensitive to copper (i.e. lower MIC) (Fig. 1).

\section{Discussion}

It's a current challenge in viticulture the reduction of the fungicides applications and find alternatives to the employ of the synthetic pesticides used in conventional farming.

Organic viticulture has become increasing popular all over the world, one of the criteria of organic viticulture is to protect vines without using synthetic chemical pesticides, replacing them with copper-based molecules.

However, previous studies have already shown that copper-based fungicides cause significant changes in the size and structure of microbial communities (Stirling et al., 1999; Tom-Petersen et al., 2003; Berg et al., 2005; Ranjard et al., 2006; Verginer et al., 2010; Martins et al., 2012).

For this reason, it is of major importance to evaluate the impact of different copper-based fungicides over the grape berry bacterial population.

The results of MIC measurements revealed that the different copper formulations have a variable inhibitory effect and among the different isolates, some species are the most resistant to all copper formulations than others.

This study confirm that usage of cupric phytosanitary products should be reasonable independently of the farming system; they also provide evidence of the importance of the choice of which copper formulations are to be used regarding their impact on the grape berry bacterial microbiota.

The authors wish to thank the Bordeaux Wine Council for financial support and the owners of Lussac vineyards for supplying grape berry samples, as well as their kind cooperation. 


\section{CuSO4+ \\ $\mathrm{Ca}(\mathrm{OH}) 2 \mathrm{Cu}(\mathrm{OH}) 2 \quad \mathrm{Cu} 2 \mathrm{O} \quad \mathrm{CuSO} 4$}

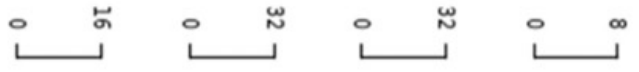

distance de $W$ ard
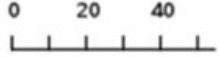
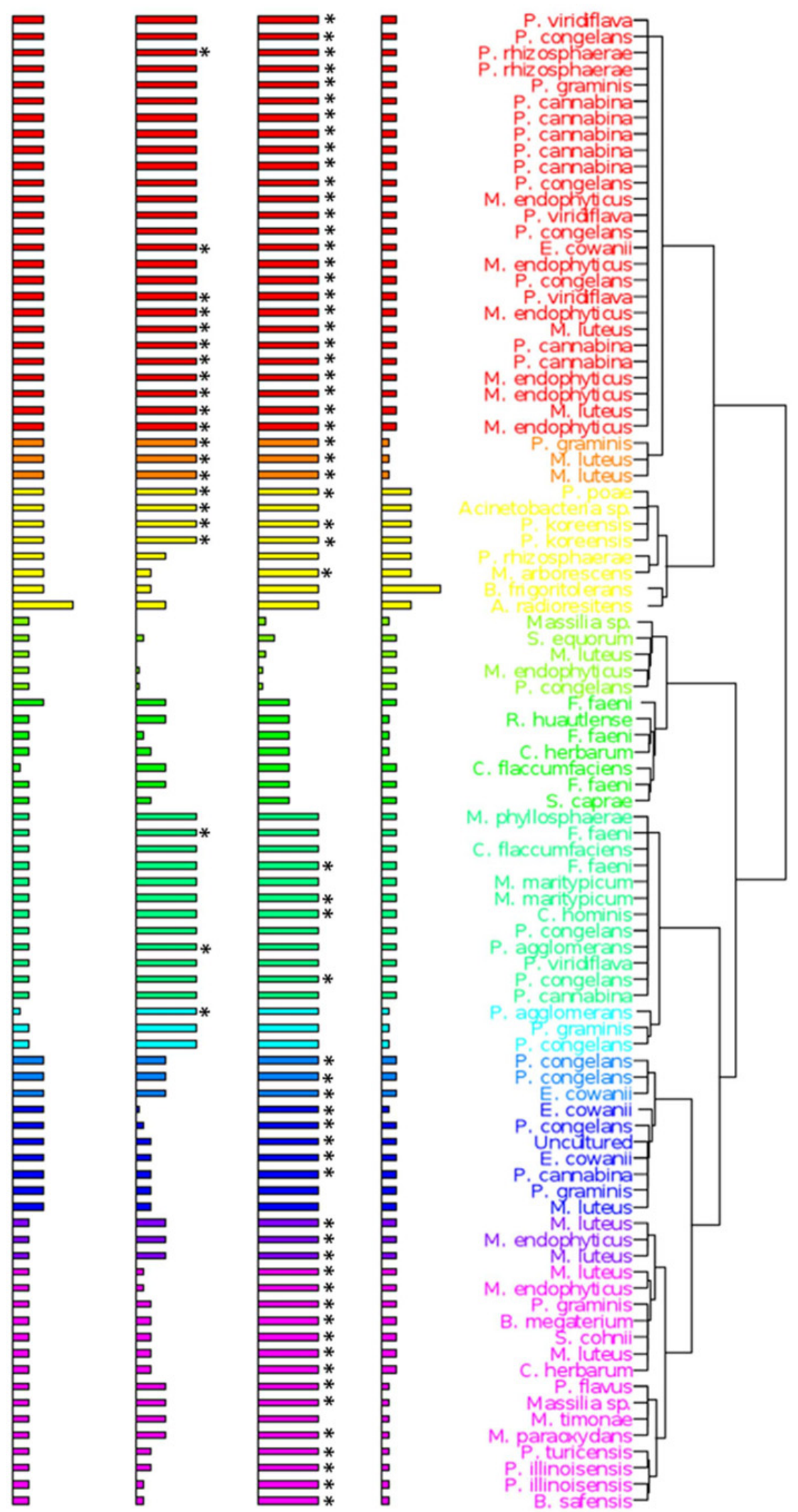

Figure 1. Ascending Hierarchical Classification of the collection of 92 bacterial, the dendrogram was establish using the MIC values of the four different copper formulations as active variables. The bars of the histogram represent the minimum inhibitory concentration of each species. * Indicates that the minimum inhibitory concentration his higher than $32 \mathrm{mg} / \mathrm{ml}$. 


\section{References}

Barbe J-C, De Revel G, Joyeux A, Bertrand A, Lonvaud-Funel A (2001) Role of botrytized grape micro-organisms in SO2 binding phenomena. J Appl Microbiol 90: 34-42

Bae S, Fleet GH, Heard GM (2006) Lactic acid bacteria associated with wine grapes from several Australian vineyards. J Appl Microbiol 100: 712-727

Berg, J., Tom-Petersen, A., Nybroe, O., 2005. Copper amendment of agricultural soil selects for bacterial antibiotic resistance in the field. Lett. Appl. Microbiol. 40, 146-151

Martins, G., Lauga, B., Miot-Sertier, C., Mercier, A., Lonvaud, A., Soulas, M.-L., Soulas, G., MasneufPomarède, I., 2013. Characterization of epiphytic bacterial communities from grapes, leaves, bark and soil of grapevine plants grown, and their relations. PLoS ONE 8, e73013

Martins, G., Miot-Sertier, C., Lauga, B., Claisse, O., Lonvaud-Funel, A., Soulas, G., Masneuf-Pomarède, I., 2012. Grape berry bacterial microbiota: impact of the ripening process and the farming system. Int. J. Food Microbiol. 158, 93-100

Nisiotou AA, Rantsiou K, Iliopoulos V, Cocolin L, Nychas G-JE (2011) Bacterial species associated with sound and Botrytis-infected grapes from a Greek vineyard. Int J Food Microbiol 145: 432-436

Stirling, A.M., Stirling, G.R., Pegg, K.G., Hayward, A.C., 1999. Effect of copper fungicide on Colletotrichum gloeosporioides and other microorganisms on avocado leaves and fruit. Aust. J. Agric. Res. 50, 1459-1468

Tom-Petersen, A., Leser, T.D., Marsh, T.L., Nybroe, O., 2003. Effects of copper amendment on the bacterial community in agricultural soil analyzed by the T-RFLP technique. FEMS Microbiol. Ecol. 46, 53-62

Ranjard, L., Lignier, L., Chaussod, R., 2006. Cumulative effects of short-termpolymetal contamination on soil bacterial community structure. Appl. Environ. Microbiol. 72, 1684-1687

Verginer, M., Leitner, E., Berg, G., 2010. Production of volatile metabolites by grape associated microorganisms. J. Agric. Food Chem. 58, 8344-8350 